\title{
Bibliography and Reviews \\ New Bulgarian Publications on Ancient History and Archaeology
}

\author{
Maya Vassileva
}

This is by no means an exhaustive review of all recent Bulgarian publications in the field. However, an attempt is made at a representative selection. The chronological range is approximately set between the (Late) Bronze Age and Late Antiquity. The grouping of the titles is both according to subject and (more or less) in chronological order.

During the last few years several publications of quite recent discoveries appeared, as well as some awaited studies on monuments and sites known for a long time.

K. Kisyov, Trakiya i Gurtsiya v drevnostta. Mogilni grobnitsi ot klassicheskata epokha v obshtina Kaloyanovo - Thrace and Greece in Ancient Times. Classical Age Tumuli in the Municipality of Kaloyanovo. Plovdiv, Avtospektar, 2005, 181 pages. Hardcover. ISBN 954-8932-35-0.

This is a welcome prompt publication of excavation results. Five Thracian tumuli in the Upper Maritsa valley (municipality of Kaloyanovo, near Plovdiv) were investigated in 2000-2003 following intense looters activity. They were part of the large Duvanliy necropolis studied by B. Filov in the 30s of the twentieth century and are dated to the $5^{\text {th }}$ - early $4^{\text {th }}$ century BC. Three sarcophagus-like stone-built tombs were unearthed, furnishing the earliest example of painted decoration in Thracian sepulchral architecture. Tumulus No. 1 contained the bones of a 20-25-year old man accompanied by rich grave goods. A large gold pectoral, silver skyphos, strainer and spoon, a bronze hydria, a basin and a breast-plate in addition to an Attic red figured hydria and a lekythos, were placed in the chamber. In the other more humble graves traces of wooden coffins were found. A number of the objects found in the 
graves display Greek craftsmanship suggesting the title of the book. However, no serious attempt has been made at a better understanding of the GreekThracian relations according to the most recent publications on the subject. According to the author, the similar burial custom in all of the tumuli speaks in favour of relatives being buried there: the $5^{\text {th }}$-century BC members of the Odrysian royal family.

The beautiful printing of the volume is to be congratulated. The text is bilingual (Bulgarian and English, the latter needs a better editing) running in two columns on each page, accompanied by very good colour photographs, black and white drawings, plans and maps.

V. Nikolov, G. Nekhrizov and Y. Tsvetkova (eds.), Spasitelni arkheologicheski razkopki po traseto na zhelezoputnata linia Plovdiv-Svilengrad prez $2004 \mathrm{~g}$. (Rescue Excavations Along the Route of the Plovdiv-Svilengrad Railroad in 2004). Veliko Turnovo, Faber, 2006, 548 pages. Hardcover. ISBN-10 954-775-606-0, ISBN-13 978-954-775-606-9 (in Bulgarian).

This beautifully printed volume is a prompt publication of the results from the rescue excavations along the route of the Plovdiv - Svilengrad (south-eastern Bulgaria) railroad in 2004. Nine archaeological sites were studied ranging in date from the Early Neolithic to medieval times. The excavations revealed settlements, tumular necropoleis, pit sanctuaries, medieval fortifications, settlements and cemeteries. All possible scientific research has been done on each of them, such as geomagnetic and geophysical prospection, geomorphological analysis of the area, anthropological studies of the human bones, and archaebotanical examination of the floral remains. Special papers on coins and flint production are also included.

It is worth noting that these rescue excavations yielded more evidence on pit sanctuaries in the Thracian lands. This kind of sites was previously rather neglected, but their number has increased significantly during the last decade or so and their careful study would contribute to the better understanding of the rituals performed in ancient Thrace.

All contributions are supplied with English abstracts, black-and-white maps, plans and drawings. In addition, at the end of the volume there are 28 colour plates. 
J. Valeva, The Painted Coffers of the Ostrusha Tomb. Sofia, Bulgarski khudozhnik, 2005, 200 pages. Paperback. ISBN-10 954-406-127-4, ISBN-13 978-954-406-127-2.

The tomb in the Ostrusha Mound near the town of Shipka, not far from Kazanluk, is a unique Thracian monument discovered in 1993. So far there is no complete publication of the entire complex. One of the distinctive features of the monolithic stone chamber placed on a stepped podium are the miniature paintings (average $0.15 \times 0.15 \mathrm{~m}$ ) on the coffered ceiling of the chamber. They are in a very bad state of preservation, being intentionally scratched and damaged as early as ancient times.

J. Valeva, an art historian, offers a minute study of the paintings in the coffers including probable reconstructions of the damaged images, their reading and interpretation in comparison with a huge number of similar ancient paintings from Greece, Macedonia, Asia Minor, Scythia and Italy. Iconographic parallels from sculptures and objects of the minor arts are also considered. In the introductory chapter she rightfully considers the architecture of the Ostrusha tomb in the context of such buildings as Cyrus tomb, the tomb at Gur-i-Dukhtar in Buzpar and the Pyramid tomb at Sardis. The Anatolian affinities of the constructions are obvious.

J. Valeva reads and interprets the images in an attempt to reconstruct the entire decorative programme of the Ostrusha tomb. This programme parallels the iconography of death known from other ancient monuments, thus offering her the opportunity to read more securely some of the badly damaged paintings. Sirens and Nereids were placed in the triangular fields in the centre, flowers and human portraits alternate in the smaller coffers, while the bigger ones along the perimeter of the ceiling contained figured scenes.

Most of the scenes are read as being episodes from Achilles' life; Thetis is also identified. Bellerophon slaying the Chimaira is represented in one of the paintings. Characters from Dionysos retinue are suggested for some of the figures. The floral decorative patterns supplement the chtonic and Dionysiac affinities. The author considers this decorative programme as a personal choice of the owner of the tomb who was influenced by the fame of the hero throughout the Greek world rather than as a reflection of an actual cult of Achilles in Thrace. Although the publication points out architectural and artistic influences and parallels from Asia Minor and Italy, the strongest claim is to the Early Hellenistic style of the Macedonian court copied and imitated by the Thracian elite. The paintings are defined as purely Greek, late Classical in style, and dated to 330-310 BC. 
The book is beautifully printed with 17 colour plates at the end and numerous black-and-white pictures in the text. In addition to the large bibliography, a separate list of the publications on the Ostrousha tomb is added. The English language is excellently edited by B. S. Ridgeway.

N. Torbov, Mogilanskata mogila vuv Vratsa. (The Mogilanska Mogila Tumulus in Vratsa). Vratsa, 2005, 200 pages. Paperback. ISBN 954-962718-7. (In Bulgarian, with an English summary).

The Mogilanska Mogila Tumulus was investigated in the winter of 1965-1966. The rescue excavations were carried out in very bad climatic conditions. Nevertheless, the rich grave goods discovered (a silver-gilt greave, a gold jug, silver phiale, a gold wreath) paid off: they have been part of almost every Thracian exhibition around the world ever since. However, due to many circumstances, the excavation documentation is in a poor state. N. Torbov, a young curator at the Museum of History in Vratsa, carefully studied the records of the excavations and came upon an unknown field book of the late Bogdan Nikolov, one of the excavation directors. So, this publication gathers all known archive documents of the Mogilanska Mogila Tumulus investigation. He publishes plans and drawings of the three constructions found in the mound for the first time. The data allows him to offer a hypothetical reconstruction of the tomb structure. He also hypothesizes on the rituals performed there. However, the real value of the publication lies in the recovered details of the archaeological study of the tumulus.

D. Vasileva, Trakiyskite grobnitsi. Arkhitekturno-metrichno izsledvane. Sus sutrudnichestvoto na Daniela Stoyanova. (The Thracian Tombs. Architectural-Metrical Study) (Studia Archaeologica Universitatis Serdicensis, Suppl. 3), Sofia, 2005, 184 pages, XII colour plates. Paperback. ISSN 1312-7284 (In Bulgarian, with an English summary).

This publication reflects the results of many years work of the architect Daphina Vasileva in architectural investigations of Thracian tombs. It was accomplished due to the efforts of one her students, a young scholar, D. Stoyanova.

The major part of this research took place before the discovery of the numerous tombs near Kazanluk, Krun and Shipka (Central Bulgaria) in the last decade or so. Nevertheless, the minute study of the architecture allows the author to argue in favour of a 'Thracian foot' equal to $29 \mathrm{~cm}$. The determination of a linear measure unit is a principal question in the investigation of 
architectural design and the tracing of Thracian monumental tombs. This unit seems to originate in the Aegean Bronze Age. Unlike the other ancient measurement systems, the Thracian linear and weight units were related and formed a closed system.

D. Draganov. Monetosecheneto na Deultum (The Miniting of Deultum). Sofia, 'Bratya Bobokovi' Foundation, 2007, 484 pages. Hardcover. ISBN 9549460029 (In Bulgarian).

This is an exquisitely printed huge volume on the coins of the Roman colony of Deultum, not far from Burgas (on the Black Sea coast). D. Draganov offers an exhaustive study on the $1^{\text {st }}-3^{\text {rd }}$ centuries $\mathrm{AD}$ issues of Deultum. It meets the modern standards of coin catalogues and publications. All the items are represented by black-and-white pictures of high quality, and some of them have colour images as well.

It is to be regretted that only few books in the field of ancient history were published.

P. Delev, Lisymachos. Sofia, St. Kliment Ohridski University Press, 2004, 463 pages. Hardcover. ISBN 954-07-1918-X (In Bulgarian).

Considering the life, the military and political career of Alexander's general, Delev reveals important features of the Early Hellenistic world. An emphasis is placed on Lysimachos being the ruler of Thrace after the death of Alexander the Great and on his political relations with the Getae and Seuthes III. The study is supplemented by a useful prosopographical entry on the closest relatives of Lysimachos, and by annexes on the coins of Lysimachos and Bulgarian translations of excerpts from the major ancient historians who furnished accounts on the Hellenistic ruler. The book is conveniently supplied with indices and a huge bibliographic section.

M. Yordanova-Alexieva, Hellenic Orphic Evidence. Sofia, LIK, 2004, 350 pages. Paperback. ISBN 954-607-652-X (In Bulgarian, with a German summary).

The recent bibliography on 'Orphic literature', ritual and mysteries is enormous. This publication by a young classicist is an attempt to summarize the discussion and organize the available evidence of Orphic texts. 
M. Yordanova-Alexieva tries to define the major ideological elements in the Orphic doctrine by considering the evidence in several groups. She reexamines the Derveni and the Gurôb papyri, the Orphic gold lamellae, a number of red-figured Attic vases from South Italy and the sacred inscribed objects from Olbia. A useful review of the archaeological context of the papyri and the other objects is offered.

As a whole the emphasis is placed on the literary evidence and on a possible reconstruction of an archetypal text. The ritual context of these texts, however, seems less well interpreted. The book can hardly make a significant contribution to the modern scholarly discussion of the subject, but is useful for the Bulgarian audience. It is supplied with four annexes of a catalogue type for the four groups of evidence, including drawings and pictures, as well as Bulgarian translations of the texts of the papyri, the gold lamellae and the objects from Olbia, and black-and-white pictures of the vases discussed, together with bibliography lists of the editions of and the publications on each group of evidence. The quality of the illustrations is not very good. An extensive German summary is found at the end of the book.

\section{Tacheva, Tsarete na drevna Trakiya. Kniga purva. (The Kings of Ancient Thrace. Book One). Sofia, Agato, 2006, 245 pages. Paperback. ISBN-10 954-8761-73-4, ISBN-13 978-954-8761-73-4 (In Bulgarian).}

The study covers the period from Darius I's march against Scythia to Seuthes III. The author discusses some debatable moments in the history of the Odrysian Kingdom and details in the political activity of the first Odrysian kings. Some of her views have already been presented in different articles.

M. Tacheva hypothesized on possible early Odrysian-Persian political relations and intermarriages, suggesting that Scythodokos might have been the anonymous brother of Sitalkes, son of Teres, whom he exchanged with Scyles according to Herodotus. Her identification of the buried persons in the Golyamata tumulus and the Bashova tumulus near Duvanli with Sparadokos and Seuthes I will remain a pure hypothesis, but paying more attention to the Thracian-Persian political and cultural interactions is welcome.

A catalogue of Getas' coins is enclosed in the chapter dealing with this elusive king of the Edonians. Gathering and extensively using the numismatic material is one of the major contributions of the study. Iconographic elements associated with royal ideology are also considered.

The author re-examines the inscription from Pistiros, offering fresh ideas on its interpretation, suggesting her own scenario for the fate of Seuthopolis and attempting a reconstruction of the political career of Seuthes III. 
M. Tacheva, Vlast $i$ sotsium v rimska Miziya $i$ Trakiya. Kniga 2. (Power and Society in Roman Moesia and Thrace. Vol. 2), Sofia, St. Kliment Obridski University Press, 2004, 207 pages. Paperback. ISBN 954-072095-8 (In Bulgarian, with a German summary).

This is a collection volume including unpublished papers presented by the author at different conferences and symposia. It is divided into two sections: historical and epigraphic studies. The first part deals with the Roman conquest of the Balkan lands and the administrative organization of the provinces of Moesia and Thrace. M. Tacheva is concerned with the urbanization of Upper and Lower Moesia at the time of the Severi, the territory of Pautalia and the strategy of Koilaletike. Re-examination of epigraphic data contributes to the discussion of some historical problems of the West Pontic and Thracian koinon. The publication benefits from a good printing quality. Several black-andwhite maps illustrate the historical issues discussed. Each chapter is supplied with an abstract in German.

\section{R. Ivanov, G. Atanassov and P. Donevski, Istoria na Silistra.I. Antichniyat Durostorum (History of Silistra. I. The Ancient Durostorum). Silistra, Sofia, Kovachev, 2006, 408 pages. Hardcover. ISBN-10 954-9388-07-7, ISBN-13 978-954-9388-07-7 (In Bulgarian).}

This book attempts to present the ancient history of the city of Silistra on the Danube, ancient Durostorum, to a wider audience. The first volume ends with the period of Late Antiquity. The publication starts with the geographical and climatic conditions of the city. The authors give a very useful account of the written sources and the maps where the name of the city (and its forms) appears. A large part of the text is devoted to the role of Dorustorum in the Roman provinces of Moesia, Lower Moesia and Moesia II as the seat of the $11^{\text {th }}$ Claudian Legion. Different chapters deal with everyday life, ethnicity of the population and the romanization in the city. Religion, festivities and necropoleis are also dealt with. A special chapter is devoted to one of the masterpieces of ancient art, the $4^{\text {th }}$ century AD painted tomb. The book is lavishly illustrated with colour and black-and-white pictures, maps, plans and drawings.

The tradition has been set that many interesting and valuable papers appear in Honorary volumes (Festschriften). Sadly enough, some of the honorees are no longer with us. 


\section{K. Jordanov, K. Porozhanov and V. Fol (eds.) Thracia 15. In honorem annorum LXX Alexandri Fol. Sofia, Tangra TanNakRa Obshtobulgarska Fondatsia, 2003, 704 pages. Hardcover. ISBN 0204-9872.}

This huge volume gathers the contributions of a number of Prof. Alexander Fol's colleagues, friends and students from Bulgaria and abroad. The list itself of the scholars' names from Germany, USA, Russia, Romania, Greece, Turkey, the Republic of Macedonia, Spain, Austria, and Serbia who contributed to the volume is impressive. The $70^{\text {th }}$ birthday of Alexander Fol stimulated many young Bulgarian archaeologists and historians to offer articles in his honour. A great number of papers are devoted to problems of Thracian religion and Thracian Orphism on which A. Fol worked for the last 20 years or so (I. Marazov, L. E. Roller, Z. Gocheva, G. R. C. Wright, A. Poruciuc, R. Neykova, D. Boteva, G. Arnaudov, D. Agre, E. Penkova, L. Konova, I. Shopova). Several papers on historical issues, which consider Thrace in the wider context of the ancient world, are worth noting (K. Jordanov, K. Porozhanov, P. Delev, H. Preshlenov, N. Stanev). A number of epigraphic articles supplement the latter. P. Dimitrov's fresh reading and interpretation of the $6^{\text {th }}$ century BC Thracian inscription from Kjolmen deserves a special mention. The number of articles on rock-cut monuments reflects the increased interest in this research field, not only in Bulgaria, but in the neighbouring countries as well (E. Beksac, T. T. Sivas, V. Fol, A. Stoev et al., I. Christov and V. Barakov). Thracian burial rites and tumuli have also received due attention (G. Kitov, R. Georgieva, D. Kotova, M. Tonkova). Other papers range from the pre-history on the Balkans to medieval topics and modern ethnological and anthropological studies.

Papers are published in English, French, German and Spanish. The volume benefited from a very good publishing quality and good black-and-white photographs and drawings.

V. Nikolov and K. Băčvarov (eds.), Von Domica bis Drama. Gedenkschrift für Jan Lichardus. Sofia, Archäologisches Institut mit Museum der Bulgarischen Akademie der Wissenschaften, 2004, 280 pages. Paperback. ISBN 954-91587-2-1.

This is a Festschrift offered to Prof. Jan Lichardus on the occasion of his $65^{\text {th }}$ anniversary, which, unfortunately, he did not live long enough to see. Contributing to the study of pre-historic sites in Europe, J. Lichardus spent the last 20 years of his career in excavating near Drama, district of Yambol, southeastern Bulgaria. The joint Bulgarian-German expedition carried out an exem- 
plary archaeological investigation of one of the most important pre-historic sites in Bulgaria. Thus, most of the papers deal with Bulgarian pre-history, ranging from the Neolithic to the Late Bronze and Early Iron Ages. However, during all these years J. Lichardus made a lot of friends among his Bulgarian colleagues, some of whom now offered papers concerned with later periods as well, the Classical and Hellenistic periods. All papers are in German with very few exceptions of English texts. The volume is supplied with very good blackand-white pictures and drawings.

\section{T. Stoyanov, S. Angelova and I. Lozanov (eds.), Stephanos Archaeologicos in honorem Professoris Ludmili Getov. (Studia Archaeologica Universita- tis Serdicensis, Suppl. 4) Sofia, St. Kliment Ohridski University Press, 2005, 740 pages. Paperback. No ISBN/ISSN.}

This is a huge volume dedicated to L. Getov, professor in classical archaeology at 'St. Kliment Ohridski' Sofia University. Although the offered articles cover a huge chronological range, from prehistory to early Byzantine and Bulgarian archaeology, the majority of them focus on classical archaeology. Many of the works fall within the major fields of interest of Prof. L. Getov: Thracian tumuli, Greek pottery and amphora stamps, architecture, etc. A number of publications consider tumuli or other sites in the area of Kazanluk (Central Bulgaria) where Prof. Getov has worked for many years. Thus, the prompt publication of the major finds from the Svetitsata tumulus (excavated in 2004) by G. Kitov and the excavations of the Kesteleva tumulus near Muglizh by D. Dimitrova are welcome. Studies on the iconography of Greek vases discovered in Thrace, as well as art studies of Thracian objects are also numerous (D. Boteva, V. Vladimirova-Paunova, R. Georgieva, Z. Gocheva, L. Konova, E. Penkova, A. Petrova, K. Rabadjiev). A number of authors took the opportunity to publish for the first time certain newly found artifacts or so far unpublished objects from museum collections (D. Antonov, L. Vagalinski, D. Damyanov, A. Dimitrova-Milcheva, D. Draganov, D. Katincharova, N. Markov, D. Momchilov, K. Panayotova, E. Paunov, E. Pencheva and A. Cholakova). Several papers re-examine and re-interpret well known objects and monuments, and a few discus historical issues. The otherwise good printing is compromised by the poor quality of the black-and-white photographs. A number of articles are published in English, the rest of them are in Bulgarian supplied with abstracts in English, French and German. 
T. Stoyanov, M. Tonkova, Ch. Preshlenov and Ch. Popov (eds.), Heros Hephaistos. Studia in honorem Liubae Ognenova-Marinova. Veliko Tarnovo, Faber, 2005, 492 pages. Paperback. ISBN 954-775-531-5.

L. Ognenova-Marinova has spent a lot of her time and research efforts in studying the Greek colonies along the western Black Sea coast. She was one of the first Bulgarian underwater archaeologists. Naturally, a number of papers are devoted to the recent investigation and research problems of Apollonia Pontica, Messambria and their hinterland (F. Cordano, I. Karayotov, B. Rousseva, K. Panayotova, L. Konova, M. Gyuzelev). L. Ognenova-Marinova’s major contribution lies in art studies. Thus, many of her colleagues chose to offer papers on different aspects of Thracian art, or the Greek iconography of objects and monuments found in Thrace. Two papers on the adoption of Greek architectural orders in Thracian sepulchral architecture deserve mentioning (Y. Vuleva and D. Stoyanova). Scholars from the Czech Republic, the Republic of Macedonia and Greece also contributed to the volume. Several papers are published in English and French, while the others are supplied with abstracts in English, French and German. The illustrations are of a better quality than those in the previously discussed volume.

The last few years saw the publication of a number of luxuriously printed books on ancient Thrace and on the history of Bulgaria (either bilingual editions or simultaneously published copies in Bulgarian and in the major western languages). Most of them are designed rather like albums or catalogues. Their value lies in the excellent quality of the colour pictures and their main goal is to promote Bulgarian ancient and medieval cultural heritage to foreign audiences. However, some of them deserve mentioning as they summarize the key contributions and scholarly achievements of their authors:

A. Fol and V. Fol, Trakite - The Thracians. Sofia, Tangra TanNakRa Obshtobulgarska Fondatsia, 2005, 208 pages. Hardcover. ISBN 954-9717-186. (parallel text in Bulgarian and English).

I. Marazov, Drevna Trakiya - Ancient Thrace. Sofia, Letera, 2005, 180 pages. No ISBN/ISSN. (copies in Russian and in the major western languages).

I. Marazov, Trakiyskiyat voyn - The Thracian Warrior. Sofia, Christo Botev, 2005, 184 pages. No ISBN/ISSN. (in Bulgarian and English).

A number of volumes have recently been published in series. The Institute of Thracology continues publishing bilingual (Greek- Bulgarian) editions of 
ancient authors. After the publication of Polybius' Histories in three volumes, the translation of Pausanias' first five books now appeared:

A. Fol (ed.), V. Russinov (transl.) Pavzanii. Opisanie na Elada. Knigi I-V (Kum izvorite za Trakiya i trakite IV). Sofia, Ral-Kolobar, 2004, 396 pages. ISBN 954-90714-3-X.

A. Fol, K. Yordanov and K. Porozhanov (eds.) Thracia 16. In honorem X congressus studiorum Thracicorum Graecia 2005. Sofia, Ral-Kolobar, 2005, 316 pages. Paperback. ISSN 0204-9872.

This is a collection of papers by Bulgarian scholars (the only exception is Dragi Mitrevski from Skopie University) presented on the occasion of the $10^{\text {th }}$ International Congress of Thracian Studies held in Greece in October 2005. They were published on the eve of the congress and do not double the contributions of the authors at the congress itself. Three papers reflect the work on an international project for an interdisciplinary study of the Strandzha region, both on Bulgarian and Turkish territory, focusing on Salmydessos (K. Porozhanov, A. Portalski, A. Stoev). Aspects of rituality, cult and religion are very popular as usual in recent years. Very few papers discuss purely historical issues (K. Jordanov, P. Delev). Four papers are devoted to ancient architecture and the Thracian contribution to it, especially in tomb constructing (M. Čičikova, D. Zheleva-Martins and Y. Furkov, P. Valev, R. Bazaytova).Papers are published in English, French and German. The printing quality is fairly good, but the volume needs a better editing: there are a lot of typographical mistakes.

After a couple of years break the 'Helis' series saw two successive volumes, 4 and 5.

D. Gergova (ed.), Helis IV. Izsledvaniya, rezultati i problemi v 'Sboryanovo' (Investigations, Results and Problems in 'Sboryanovo'). Sofia, Marin Drinov Academic Publisher, 2005, 288 pages. Paperback. ISBN 954-322-056-5. (In Bulgarian, with English abstracts).

The fourth volume presents the current state of the interdisciplinary study of the complex archeological site of Sboryanovo, near Isperikh, north-eastern Bulgaria. Naturally, several papers deal with the research of the already famous Sveshtari tomb with karyatids and painted decoration (M. Čičikova, C. Coupry, S. Koynova-Mechkueva). The results of the scientific research both of the tomb and of the area are presented there, namely of geological, geomorphological, petrographic, archaeobotanical and physical anthropological studies 
(J. Jordanov and S. Cholakov, I. Katevski and D. Monna, J. Ivanov and Chr. Pimpirev, Tsv. Popova). Some papers deal with early medieval and modern folklore issues, as sacred places and sanctuaries that had been frequented for millennia have been found in the 'Sboryanovo' complex (D. Ovcharov, S. Koynova-Mechkueva, E. Venedikova, N. Dermendjiev, J. Atanassov). A selected bibliography of the studies on the 'Sboryanovo' archaeological reserve is added at the end of the volume. All papers have English abstracts.

D. Gergova (ed.), Helis V. Mezhdunarodna konferentsiya Getite - kultura $i$ traditsii. 20 godini prouchvania na Sveshtarskata grobnitsa i rezervata "Sboryanovo". Krugla masa 'Nasheto obshto nasledstvo' Arkheologicheskiyat rezervat (International Conference 'The Getae - Culture and Traditions. 20 Years Research of the Sveshtari Tomb and the Sboryanovo Reserve'. Round Table 'Our Heritage' the Archaeological Reserve). Sofia, Marin Drinov Academic Publisher, 2006, 579 pages. Paperback. ISBN-10: 954-322124-3, ISBN-13: 978-954-322-124-0.

Helis $\mathrm{V}$ is a larger volume as it is the publication of the proceedings of an international conference on the Getic history and culture which celebrated the $20^{\text {th }}$ anniversary of the discovery of the Sveshtari tomb. This scholarly meeting was an opportunity to place the study of the Sveshtari tomb in the wider context of the Early Hellenistic sepulchral architecture. It also presented the current state of the restoration and conservation activities, now that the tomb has recently been opened to the public. Like the previous volume, this one also reflects the interdisciplinary nature of the investigation of the area. Here one can find a few more attempts at summarizing the important issues of the history, art and religion of the Thracian Getae.

Understandably, more foreign scholars published in this volume. All Bulgarian papers are supplied with English abstracts. The better printing quality of the publication should be acknowledged.

I. Iliev (ed.), IV Mezhdunaroden symposium Poselishten zhivot v Trakia. 9-11 noemvri 2005, Yambol - Kabyle - IVth International Symposium Settlement Life in Thrace. November 9-11, 2005. Yambol, Ya Publishers, 2006. 352 pages. Paperback. ISBN-10 954-615-130-0, ISBN-13 978-954615-130-8.

This volume publishes the proceedings of the last in a series of regular symposia, previously entitled 'Kabyle'. Naturally, papers on the current state of the 
studies of Kabyle (near the present-day city of Yambol, south-eastern Bulgaria) prevail. There are papers on Philipopolis (M. Martinova-Kyutova and S. Cherneva) and Deultum (P. Balabanov) as well. Several sites near Belovo (district of Plovdiv) are also discussed. A contribution by D. Agre and D. Dichev is worth mentioning as it publishes Iron Age fibulae discovered in several dolmens in the Strandzha Mountains recently excavated. The prompt publication of a very rich grave under a tumulus near the villages of Malomirovo and Zlatinitsa (south-eastern Bulgaria) by D. Agre is to be congratulated. It was excavated in 2005 and some of its spectacular grave goods have already been included in Thracian exhibitions abroad (two silver-gilt rhyta, a silver greave, a bronze helmet, a quiver full of arrows, etc.). All papers are published in English, French and German. The volume is supplied with many black-and-white pictures, maps, plans and drawings.

J. Bouzek and L. Domaradzka (eds.), The Culture of Thracians and their Neighbours. Proceedings of the International Symposium in Memory of Prof. Mieczyslaw Domaradzki, with a Round Table "Archaeological Map of Bulgaria" (BAR International Series 1350). Oxford, Archaeopress, 2005, 282 pages. Paperback. ISBN 1-84171-696-0.

Although it is not a Bulgarian publication this volume honours the memory of a Polish archaeologist, Mieczyslaw Domaradzki, who excavated in Bulgaria for more than 20 years, and the majority of its contributors are Bulgarian scholars. The present volume is a delayed publication of the proceedings of an international conference in his memory (held in September-October, 1999). Its title was suggested by the new evidence which has shown that contacts and interactions between ancient Thrace and the Greek world were more intense and varied than previously imagined. The papers are grouped into several major topics related to the scope of M. Domaradzki's research: emporion Pistiros, settlements studies, burial rites and cult places and a section that gave the name to the volume, as well as a round table on the Archaeological Map of Bulgaria. The papers present the most recent achievements in the investigation of the emporion Pistiros and announce the results of recent excavations of other Thracian settlements. With the current interest in Thracian tombs and gold finds, it is a welcome collection of articles on settlement and urban studies in ancient Thrace.

For the sake of chronology a group of publications dealing with Roman (and Late Antiquity) archaeology are considered at the end. 
R. T. Ivanov (ed.), Arkheologia na bulgarskite zemi. Tom 1. (Archaeology of Bulgarian Lands. Vol. 1.). Ivrai, Sofia, 2006, 314 pages. Paperback. ISBN 954-9388-02-6 (In Bulgarian, with English abstracts).

Almost 25 years ago the Institute of Archaeology planned to publish the "Archaeology of Bulgaria" in several volumes. This project has never been accomplished. That is why the scholars from the Classical Archaeology Department at the Institute decided to publish their volume on the Roman period (from Octavian Augustus, 17 BC- 14 AD to Diocletian, 284-305 AD). This collection includes chapters by scholars from other institutions as well: universities, local museums, other institutes at the Bulgarian Academy of Sciences. This is meant as an academic publication on the life and culture on the present-day Bulgarian territory in Roman time. On the basis of the latest archaeological discoveries and achievements in ancient history scholarship the authors present the urbanization, architecture, building techniques, road network, water supply system, warfare and legion camps, and crafts. The book is beautifully printed, furnished with very good pictures, maps and drawings. The illustration captions are written both in Bulgarian and English.

M. Madzharov, Rimskiyat put Eskus-Filipopol. Putni stantsii $i$ selishta (Oescus-Philippopolis Roman Road. Road Stations and Settlements). Plovdiv, 2004, 124 pages. Hardcover. ISBN 954-91038-8-9 (In Bulgarian, with an English summary).

The author discusses a number of archaeological sites on the route of the Roman road. An important part of the study is the collected epigraphic evidence for the stations and settlements considered. The following sites are included in the study: Oescus, Ad Putea, Storgosia, Dorionibus, Melta, Sostra, Ad Radices, Montemno, Sub Radice, Viamata and Philippopolis. Black-andwhite pictures, maps, plans and drawings illustrate the text.

V. Katsarova, Pautalia $i$ neinata teritoriya prez I-IV vek (Pautalia and its Territory in the $1^{\text {st }} 4^{\text {th }}$ century $\left.A D\right)$. Veliko Turnovo, Faber, 2005. 328 pages. Paperback. ISBN 954-775-522-6 (In Bulgarian, with a German summary).

This publication is an attempt at organizing and interpreting the archaeological study of the Roman city of Pautalia (modern Kyustendil, south of Sofia; 
the most western part of the Province of Thrace, later Inner Dacia). The many year archaeological investigation of the city and the area furnished a large quantity of data about the development of the Roman city in different historical periods up to Late Antiquity ( $6^{\text {th }}$ century AD). The author applies an interdisciplinary approach in this study, examining the archaeological, epigraphic and historical data. V. Katsarova attempts at reinterpreting the available evidence according to modern standards of Spatial Archaeology, which is a new trend in Bulgarian archaeological studies.

A theoretical chapter considers the terminology and the meaning of 'territorium' in the Roman provincial system. Pautalia was founded in the $2^{\text {nd }}$ century AD. No large earlier settlement seems to have existed before the Romans founded the city near the famous thermal springs. She summarizes the already excavated buildings and streets of ancient Pautalia and the area in an attempt to follow the role of the city in the provincial system. Special attention is paid to the road and settlement network in the region in order to better clarify the administrative and economic relations of the city with her territorium. Although Pautalia was later the seat of an archbishop, the evidence for an early spread of Christianity is scarce. The votive plates in a number of sanctuaries (for example, that of Zeus and Hera, near the village of Kopilovtsi) in the area testify to the persistence of the old pagan cults.

A. Dimitrova-Milcheva and V. Katsarova (eds.), Spartacus II. 2075 godini of vustanieto na Spartak. Trako-rimsko nasledstvo. 2000 godini khristiyanstvo. Mezhdunaroden symposium 1-4 oktomvri 2002 godina. Sandanski (2075 th Anniversary of Spartacus' Uprising. Thracian-Roman Heritage. 2000 Years of Christianity. An International Symposium, October 1-4, 2002, Sandanski.). Veliko Turnovo, Faber, 2006, 336 pages. Paperback. ISBN-10 954-775-553-6, ISBN-13 978-954-775-553-6.

This volume publishes the proceedings of an international symposium. As the title shows the papers focus on the Thracian lands in Roman and Late Antique/Early Medieval times. However, the only paper that has any bearing to Spartacus is about representations of gladiators from Romania (D. Bondoc). The southwestern Thracian lands are the preferred geographical range of the studies presented. A few papers deal with pre-Roman issues like the $1^{\text {st }}$ millennium BC wheel-made monochrome pottery from south-western Thrace. Several authors are concerned with tumuli of the Roman period (C. Ioakimidou-Kontsé, M Jovanov, L. Staykova-Aleksandrova). Problems of Thracian religion (resp. of Romanization), as well as early Christianity are also discussed 
(D. Gergova, Z. Gocheva, V. Naidenova, R. Nenova-Merdzhanova, C. Preshlenov). Late Roman and Late Antique objects and monuments are presented in a number of papers. Some newly found early Christian buildings are published for the first time (K. Shalganob, M. Ivanov). All Bulgarian papers have English abstracts. The volume contains many black-and-white pictures, maps, plans and drawings.

I. Christov, G. Kitov, M. Ivanova and M. Binev, Sostra. Prouchvane na rimskata krayputna stantsiya $i$ kastel na putya Eskus - Philippoplis. I. (Sostra. Studies on the Roman Road Station and Castelum on the Oeskus - Philippoplis Road. I.) Veliko Turnovo, Faber, 2003. 152 pages. Hardcover. No ISBN/ISSN (In Bulgarian, with an English summary).

The Roman road station Sostra is situated near the village of Lomets, district of Troyan (north-central Bulgaria), just midway on the road Ulpia Oescus Philipopolis. The team attempts to summarize the results from the many-year archaeological investigations of the site and its immediate vicinity. The authors have also tried to situate the results achieved so far in a historical framework. Thus, in one chapter they consider the place of Sostra in the administrative system of the Roman provinces of Thracia and Lower Moesia. Another chapter gathers and presents the available epigraphic evidence from Sostra: 12 inscriptions in total, 4 have previously been published by B. Gerov, the rest of them are published for the first time. Settlements and road constructions beyond Sostra are also discussed. Domestic buildings, a kiln and an Early Christian basilica were discovered. G. Kitov publishes a catalogue of the finds from the $2^{\text {nd }}-3^{\text {rd }}$ century AD necropolis at Lomets-Dulbok Dol, as well as those from a flat necropolis and a mausoleum in the area. 